\title{
O Papel do Papilomavírus Humano na Carcinogênese Bucal
}

\author{
The Role of Human Papillomavirus in Oral Carcinogenesis
}

\author{
Luciana Estevam Simonato' , Glauco Issamu Miyahara²
}

\section{Resumo}

Os estudos realizados nos últimos anos com auxílio de novas tecnologias de detecção viral permitem considerar o papilomavírus humano como um agente causal do câncer de colo de útero. Além da interação com as regiōes genitais, outros sítios anatômicos têm sido acometidos pelo papilomavírus humano, tendo destaque as regiōes de cabeça e pescoço. O seu envolvimento direto com os carcinomas orais não foi ainda devidamente comprovado, todavia a sua ação sinérgica com os outros carcinógenos químicos e físicos, em determinados carcinomas epidermóides, parece ser o caminho mais correto para explicar o papel do papilomavírus humano na carcinogênese bucal.

Palavras-chave: Papilomavírus humano, Carcinogênese, Câncer bucal 


\section{INTRODUÇÃO}

\section{Papilomaví́Rus humano}

Os papilomavírus humanos (HPV) são classificados na família Papillomaviridae, gênero Papilomavírus. São vírus não-envelopados, epiteliotrópicos, de simetria icosaédrica, com 72 capsômeros e um genoma de DNA de fita dupla circular, constituindo-se de aproximadamente 6.800 a 8.400 pares de bases ${ }^{1}$.

O genoma do HPV pode ser dividido em três regiōes: uma região longa de controle (LCR), compreendendo cerca de $10 \%$ do genoma, e regióes precoces $(\mathrm{E}-$ early) e tardia $(\mathrm{L}-\text { late })^{2}$.

A região reguladora LCR (Long Control Region) ou URR (Upstream Regulatory Region) varia de 400 a 1000 pares de bases; localiza-se entre as regiōes L1 e E6 e contém as seqüências estimuladoras e repressoras da transcrição viral, além da seqüência de origem de replicação ${ }^{3,4}$. A região $\mathrm{E}$ é formada pelos genes $\mathrm{E} 1, \mathrm{E} 2$, E3, E4, E5, E6 e E7; dentre esses, E1 tem relação com a replicação viral, E2 com a transcrição e replicação, E4 com a maturação viral e alteração da matriz intracelular. Os genes E5, E6 e E7 estão envolvidos na transformação celular. A região L é formada pelos genes L1 e L2, que codificam as proteínas do capsídeo ${ }^{3,5,6}$. Assim, as regiōes E são expressas logo após a infecção e codificam as proteínas envolvidas na indução e na regulação da síntese de DNA, enquanto as regiōes L são expressas em estágios posteriores da infecção, sendo responsáveis por codificar as proteínas do capsídeo viral ${ }^{2}$.

Os HPV são um grupo heterogêneo de vírus ${ }^{7}$. As análises de sequiências de DNA têm permitido identificar mais de 100 tipos virais ${ }^{8}$. Destes, 24 tipos foram associados com lesões orais ${ }^{9}$. Sendo conhecido que os tipos 6 e 11 estão envolvidos nas lesões benignas do epitélio bucal, e os tipos 16 e 18 são comprovadamente carcinogênicos e possivelmente envolvidos na etiologia de determinados carcinomas orais ${ }^{10,11}$. Atualmente, considera-se um novo tipo de HPV quando as seqüências de nucleotídeos dos genes L1, E6 e E7 (aproximadamente 30\% do genoma viral) diferirem em mais de $10 \%$ dos tipos conhecidos. Se esse percentual for menor do que $2 \%$, então o novo vírus isolado é designado como uma variante do mesmo tipo. Os subtipos virais correspondem a genomas cuja seqüência nucleotídica nessas regiōes gênicas diferem entre $2 \%$ e $10 \%$ dos tipos já descritos ${ }^{3}$.

De acordo com o potencial de risco de desenvolvimento de neoplasias malignas em humanos, a Agência Internacional para Pesquisa do Câncer, em 1997, classificou os HPV 16 e 18 como carcinogênicos em humanos (grupo 1); os HPV 31 e 33 como provavelmente carcinogênicos em humanos (grupo 2A); e alguns dos tipos remanescentes de HPV como possivelmente carcinogênicos em humanos (grupo $2 \mathrm{~B}$ ) ${ }^{12}$. Outra classificação, quanto ao potencial de malignidade, feita por de Villiers ${ }^{13}$, tipifica-os em baixo $(6,11)$, intermediário $(31,33,35)$ ou alto risco de malignidade $(16,18)$. Podem ser classificados também de acordo com o sítio anatômico de infecção e/ou análise filogenética em HPV mucosos e HPV cutâneos, ou seja, podem ser classificados segundo o seu tropismo como: cutaneotrópicos e mucosotrópicos ${ }^{4}$.

Foi sugerido que o HPV é ubíquo e que achados comuns dos mesmos tipos de $\operatorname{HPV}(6,11,16$ e 18) em mucosas genital e bucal são um forte indicativo para a transmissão orogenital ${ }^{14}$. Esse vírus tem um amplo tropismo por epitélio de mucosa, podendo ser adquirido por transmissão sexual ${ }^{15}$. A maioria das infecçōes por HPV é produto de uma auto-inoculação de um sítio genital ou bucal próprio para o outro ${ }^{16}$. Pode também ser transmitido, ainda precocemente, durante o nascimento, do trato genital da mãe para a cavidade bucal da criança $a^{12}$.

\section{CÂNCER BUCAL}

O câncer bucal é um grave problema de saúde pública no Brasil. Estimou-se, para 2006, 13.470 novos casos, ocupando o quinto lugar entre os tumores que acometem os homens e o sétimo entre as mulheres ${ }^{17}$. É considerado o câncer mais comum da região de cabeça e pescoço, excluindo-se o câncer de pele ${ }^{18}$.

Dentre os cânceres de boca, o carcinoma espinocelular representa aproximadamente $90 \%$ das neoplasias malignas. Acomete principalmente indivíduos do sexo masculino, com mais de 40 anos de idade, embora um número crescente desta doença venha sendo documentado em adultos jovens nos últimos anos ${ }^{17}$.

Alguns dos fatores de risco para o carcinoma espinocelular são: tabaco, álcool, noz de betel, exposição prolongada ao sol, imunossupressão e infecção por vírus $^{19}$. Embora o tabaco seja um fator etiológico bem estabelecido na carcinogênese bucal, apenas um reduzido número de usuários desenvolve câncer, como também é notada a ocorrência de câncer bucal em não-usuários de tabaco e álcool ${ }^{20}$. Isto indicaria que outros fatores, incluindo susceptibilidade genética individual, agentes externos como dieta e infecção viral, podem ter uma relação sinérgica na gênese de tumor bucal ${ }^{7,821-24}$. Dentre os vírus que infectam os tecidos orais e que são prováveis agentes oncogênicos, pode-se citar o citomegalovírus, o herpesvírus e o papilomavírus humano ${ }^{21,25}$.

A ação da infecção pelo HPV na etiologia do câncer bucal foi inicialmente indicada por Syrjänen et al. ${ }^{26}$, em 
1983. A partir de então, vários estudos na literatura relatam a prevalência do HPV em tecidos orais, variando de 0 a $100 \%$ em tumores e lesões potencialmente malignas, refletindo as inerentes variações nas diferentes populações e métodos de detecção utilizados ${ }^{24,27}$, como pode ser observado na Tabela 1. Assim, os estudos do envolvimento do HPV na iniciação e na progressão das neoplasias orais têm gerado resultados conflitantes ${ }^{12,24}$.

Diversas técnicas em biologia molecular têm sido empregadas para a detecção do HPV, tais como: captura híbrida, hibridizações Southern blot ${ }^{28,37}$, Northern blot, dot blot ${ }^{31}$ e in situ ${ }^{29,30,37,39}$, além da reação em cadeia de polimerase $(\mathrm{PCR})^{32-47}$. Essas técnicas apresentam sensibilidade e especificidade amplamente variáveis ${ }^{43,48}$, sendo a PCR uma das mais empregadas nas diversas áreas de diagnóstico molecular, devido à sua grande capacidade de detectar pequenos fragmentos de $\mathrm{DNA}^{49}$.
Quanto à população estudada, tem sido sugerido que a prevalência de infecção é mais alta em lesōes orais de pacientes da Índia e mais baixa nos países ocidentais (América do Norte e Brasil) ${ }^{35}$, o que influi significativamente nos resultados, além do fato de que quanto maior for a amostra empregada no estudo, mais confiáveis serão os resultados.

Um outro aspecto a ser destacado, e não menos importante, é o tipo de material analisado. Miller e White $^{48}$ verificaram a presença do HPV mais freqüentemente em tecido fresco $(51,6 \%)$ do que naquele incluído em parafina $(21,7 \%)$, sendo esse achado explicado pelo fato de os processos de formolização, parafinização e desparafinização serem capazes de degradar o DNA, dificultando a detecção viral.

Por outro lado, o papel dos HPV de alto risco na carcinogênese oral tem se tornado mais evidente a cada

Tabela 1. Prevalência do HPV em estudos com câncer de boca

\begin{tabular}{|c|c|c|c|c|}
\hline Estudo & $\begin{array}{l}\text { Método de } \\
\text { detecção }\end{array}$ & $\begin{array}{l}\text { Tipo de } \\
\text { material }\end{array}$ & HPV + & $\%$ \\
\hline de Villiers et al., $1985^{28}$ & Southern blot & Tecido parafinado & $2 / 7$ & 28,5 \\
\hline Syriänen et al., $1988^{29}$ & ISH & Tecido parafinado & $6 / 51$ & 11,8 \\
\hline Zeuss et al., $1991^{30}$ & ISH & Tecido parafinado & $0 / 15$ & 0 \\
\hline Shindoh et al., $1992^{31}$ & PCR, dot blot & Tecido parafinado & $8 / 24$ & 33,3 \\
\hline Ostwald et al., $1994^{32}$ & PCR & Tecido fresco & $16 / 26$ & 61,5 \\
\hline Balaram et al., $1995^{33}$ & PCR & Tecido fresco & $67 / 91$ & 73,6 \\
\hline Cruz et al., $1996^{34}$ & PCR & Tecido fresco & $19 / 35$ & 54,3 \\
\hline Elamin et al., $1998^{35}$ & PCR & Tecido parafinado & $14 / 28$ & 50 \\
\hline Matzow et al., $1998^{36}$ & PCR & Tecido fresco & $0 / 38$ & 0 \\
\hline Gillison et al., $2000^{37}$ & $\begin{array}{l}\text { PCR, ISH, } \\
\text { Southern blot }\end{array}$ & Tecido fresco & $10 / 84$ & 12 \\
\hline Sisk et al., $2000^{38}$ & PCR & Tecido fresco & $11 / 22$ & 50 \\
\hline Bouda et al., $2000^{27}$ & $\mathrm{nPCR}$ & Te cido parafinado & $18 / 19$ & 94,7 \\
\hline \multirow[t]{2}{*}{ Uobe et al., $2001^{39}$} & in situ PCR & Tecido parafi nado & $20 / 20$ & 100 \\
\hline & ISH & & $0 / 20$ & 0 \\
\hline Nagpal et al., $2002^{40}$ & PCR & $\begin{array}{l}\text { Tecido fresco e } \\
\text { parafinado }\end{array}$ & $37 / 110$ & 33,6 \\
\hline Chang et al., $2003^{41}$ & hemi-nPCR & Tecido parafinado & $51 / 103$ & 49,5 \\
\hline Báez et al., $2004^{42}$ & PCR & Tecido fresco & $13 / 36$ & 25 \\
\hline Zhang et al., $2004^{43}$ & PCR & Tecido parafinado & $54 / 73$ & 74 \\
\hline Ibieta et al., $2005^{44}$ & $\mathrm{nPCR}$ & Tecido fresco & $21 / 50$ & 42 \\
\hline Tachezy et al., $2005^{45}$ & PCR & Tecido parafinado & $3 / 12$ & 25 \\
\hline Nemes et al., $2006^{46}$ & PCR & Tecido parafinado & $33 / 79$ & 42 \\
\hline Rivero et al., $2006^{47}$ & PCR & $\begin{array}{l}\text { Tecido fresco e } \\
\text { parafinado }\end{array}$ & $0 / 40$ & 0 \\
\hline
\end{tabular}


dia. A maioria dos trabalhos publicados envolvendo o papel do vírus nesse processo, nos mais diversos países, tem mostrado um índice de positividade mínimo de $20 \%{ }^{50}$.

\section{CARCINOGÊNESE BUCAL}

A infecção pelo HPV é iniciada quando uma partícula viral penetra nas células basais ou em células que estão transitoriamente se dividindo, localizada nas camadas mais baixas do epitélio estratificado. Conforme as células mais profundas do epitélio vão se dividindo, elas migram da camada basal e se tornam gradativamente diferenciadas ${ }^{4}$. Depois de entrar na célula, os genomas dos HPV são estabilizados na forma de elementos extracromossômicos nos núcleos, e o número de cópias é aumentado para aproximadamente 50 a 100 cópias por célula. Ao se dividirem, essas células infectadas distribuem eqüitativamente o DNA viral entre as célulasfilhas. Uma das células-filhas migra para a camada basal e inicia o programa de diferenciação. A outra célulafilha continua diferenciada na camada basal, sofrendo divisões para oferecer células para a manutenção da camada basal. No entanto, a célula agora corresponde a um reservatório de DNA viral para posteriores divisões celulares ${ }^{4,5,51}$.

Nas células basais e parabasais, o DNA viral replica em um baixo padrão e apenas genes precoces são transcritos. Multiplicação extensiva do DNA viral e transcrição de todos os genes virais, bem como formação de capsídeo, ocorrem apenas nas camadas mais superficiais do epitélio. Portanto, partículas virais maduras (com capsídeos completos) estão ausentes nas células basais, e a replicação produtiva do HPV está restrita às células nos estratos espinhoso e granuloso ${ }^{52}$.

Os primeiros genes dos HPV a se expressarem são E1 e E2, cujos produtos estão envolvidos na replicação do genoma viral ${ }^{51}$. O produto do gene E1, uma fosfoproteína nuclear com atividade ATPase e DNA helicase, liga-se na origem de replicação do DNA viral, sendo essencial para a replicação do vírus. A proteína codificada pelo gene E2 é um fator que regula a transcrição dos oncogenes E6 e E75'.

A proteína E4 é detectada apenas nas camadas mais diferenciadas do epitélio, estando envolvida na maturação e na liberação das partículas dos HPV. Recentes evidências sugerem que o gene E5 do HPV-16 pode induzir transformação em células epiteliais, possivelmente aumentando a transdução de sinal intracelular mediado por fatores de crescimento ${ }^{53}$.

A proteína E6 tem sua atividade transformadora dependente da ligação com a proteína supressora de tumor p53, que regula a passagem pelas fases G1/S e G2/M. Uma vez estabelecida essa ligação, a proteína
E6 estimula a degradação da p53, levando-a a níveis muito baixos em muitos tumores humanos, o que faz com que as células desses tumores falhem na parada do ciclo celular em G1, seguindo então o dano no DNA celular. Logo, se outra proteína supressora de tumor (como a pRb, por exemplo) não compensar a reduzida atividade da $\mathrm{p} 53$, a transformação celular pode, de fato, ocorrer $^{12}$. A proteína $\mathrm{E} 6$, além de reprimir a ação de p53, também tem como função a atividade de telomerase, podendo associar-se com proteínas ligantes do cálcio, ERC55, fatores de resposta do interferon, IRF3, ou, até mesmo, associar-se a proteínas de integração viral ${ }^{51}$.

A principal função do gene E7 dos HPV de alto risco é desregular a maquinaria do ciclo celular da célula infectada, principalmente pela indução da transcrição da fase G1/S. A proteína $\mathrm{E} 7$ liga-se às proteínas da família $\mathrm{pRb}$ (proteína supressora de tumor de retinoblastoma); essa interação ativa os fatores de transcrição E2F, que são liberados da $\mathrm{pRb}$. Estes fatores induzem a transcrição de genes importantes no controle da divisão celular, por promover a progressão do ciclo celular, atuando nas fases G1 e S21.

Assim, os genes E5, E6 e E7 do HPV induziriam a transformação celular e poderiam estar envolvidos na carcinogênese ${ }^{53}$, sendo os genes E6 e E7 considerados os genes de maior poder de transformação dos HPV.

Estudos desenvolvidos até a atualidade não nos permitem definir, com precisão, o papel do HPV na carcinogênese bucal; no entanto, na cérvice uterina, o mesmo já se encontra bem estabelecido ${ }^{53}$. A enorme discrepância na incidência desse vírus em lesões malignas, encontrada nos mais variados trabalhos da literatura ${ }^{27}$, contribui para a dúvida. Por outro lado, a maioria dos trabalhos publicados, envolvendo o papel do vírus nesse processo, tem mostrado um índice de positividade mínimo de $20 \%{ }^{12}$.

\section{CONCLUSÃO}

Com o avanço da tecnologia e o advento de novas técnicas moleculares, a detecção de HPV tornou-se cada vez mais precisa, permitindo correlacionar o vírus ao desenvolvimento de alguns tipos de câncer, com maior ênfase para o carcinoma espinocelular bucal. Estudos realizados nos últimos anos permitem considerar o HPV como o agente causal do câncer de colo de útero. No entanto, ainda se está longe de se poder estabelecer com precisão o real papel desse vírus no câncer bucal. A presença de diversos carcinógenos, atuando simultaneamente, impede conclusôes mais precisas e apontam mesmo para uma atuação sinérgica do HPV com outros carcinógenos químicos e físicos, 
o que de fato potencializaria o desenvolvimento de uma neoplasia maligna.

\section{REFERÊNCIAS}

1 Nelson LM, Rose RC, Moroianu J. Nuclear import strategies of high risk HPV16 L1 major capsid protein. J Biol Chem. 2002;277(26):23958-964.

2 zur Hausen H. Papillomavirus infections - a major cause of human cancers. Biochim Biophys Acta. 1996;1288(2):F55-78.

3 Burd EM. Human papillomavirus and cervical cancer. Clin Microbiol Rev. 2003;16(1):1-17.

4 Silva AMTC, Amaral MVT, Cruz AD. O papel do papiloma vírus humano no câncer. Biotecnol Cienc Desenvol. 2003;29:48-54.

5 Fehrmann F, Laimins LA. Human papillomaviruses: targeting differentiating epithelial cells for malignant transformation. Oncogene. 2003;22(33):5201-207.

6 Lin BY, Makhov AM, Griffith JD, Broker TR, Chow LT. Chaperone proteins abrogate inhibition of the human papillomavirus (HPV) E1 replicative helicase by the HPV E2 protein. Mol Cell Biol. 2002;22(18):6592-604.

7 Souto RM, Falhari JPBB, Cruz AD. O papilomavírus humano: um fator relacionado com a formação de neoplasias. Rev Bras Cancerol. 2005;51(2):155-60.

8 Scully C. Oral squamous cell carcinoma: from a hypothesis about a virus, to concern about possible sexual transmission. Oral Oncol. 2002;38(3):227-34.

9 Terai M, Burk RD. Complete nucleotide sequence and analysis of a novel human papillomavirus (HPV 84) genome cloned by an overlapping PCR method. Virology. 2001;279(1):109-15.

10 Oliveira MC, Soares RC, Pinto LP, Costa ALL. HPV e carcinogênese oral: revisão bibliográfica. Rev Bras Otorrinolaringol. 2003;69(4):553-59.

11 Syrjänen S. Human papillomavirus (HPV) in head and neck cancer. J Clin Virol. 2005;32(suppl 1):S59-66.

12 Sugerman PB, Shillitoe EJ. The high risk human papillomaviruses and oral cancer: evidence for and against a causal relationship. Oral Dis. 1997;3(3):130-47.

13 de Villiers EM. Heterogeneity of the human papillomavirus group. J Virol. 1989;63(11):4898-903.

14 Shima K, Kobayashi I, Saito I, Kiyoshima T, Matsuo K, Ozeki S, et al. Incidence of human papillomavirus 16 and 18 infection and p 53 mutation in patients with oral squamous cell carcinoma in Japan. Br J Oral Maxillofac Surg. 2000;38(5):445-50.

15 Llewellyn CD, Johnson NW, Warnakulasuriya KAAS. Risk factors for squamous cell carcinoma of the oral cavity in young people a comprehensive literature review. Oral Oncol. 2001;37(5):401-18.
16 Lynch DP. Oral viral infections. Clin Dermatol. 2000;18(5):619-28.

17 Instituto Nacional de Câncer / Ministério da Saúde. Estimativa 2006: incidência de câncer no Brasil. Rio de Janeiro: INCA; 2005.

18 Dedivitis RA, França CM, Mafra ACB, Guimarães FT, Guimarães AV. Características clínico-epidemiológicas no carcinoma espinocelular de boca e orofaringe. Rev Bras Otorrinolaringol. 2004;70(1):35-40.

19 Miller CS, Johnstone B. Human papillomavirus as a risk factor for oral squamous cell carcinoma: a meta-analysis, 1982-1997. Oral Surg Oral Med Oral Pathol Oral Radiol Endod. 2001;91(6):622-35.

20 Ko YC, Huang YL, Lee CH, Chen MJ, Lin LM, Tsai CC. Betel quid chewing, cigarette smoking and alcohol consumption related to oral cancer in Taiwan. J Oral Pathol Med. 1995;24(10):450-53.

21 Hanahan D, Weinberg RA. The hallmarks of cancer. Cell. 2000;100(1):57-70.

22 Oliveira MC, Soares RC, Costa ALL. Ação oncogênica do papilomavírus humano. Rev Bras Patol Oral. 2002;1(1):29-38.

23 Silva MAS, Maranhão VF, Carvalho AAT, Leão JC. O papel do HPV na etiologia do câncer de boca. Rev ABO Nac. 2005;12(6):349-54.

24 Soares CP, Malavazi I, Reis RI, Neves KA, Zuanon JAS, Neto $\mathrm{CB}$, et al. Presença do papilomavírus humano em lesôes malignas de mucosa oral. Rev Soc Bras Med Trop. 2002;35(5):439-44.

25 Rhodus NL. Oral cancer: leukoplakia and squamous cell carcinoma. Dent Clin North Am. 2005;49(1):143-65.

26 Syrjänen K, Syrjänen S, Lamberg M, Pyrhonen S, Nuutinen J. Morphological and immunohistochemical evidence suggesting human papillomavirus (HPV) involvement in oral squamous cell carcinogenesis. Int J Oral Surg. 1983;12(6):418-24.

27 Bouda M, Gorgoulis VG, Kastrinakis NG, Giannoudis A, Tsoli E, Danassi-Afentaki D, et al. "High risk" HPV types are frequently detected in potentially malignant and malignant oral lesions, but not in normal oral mucosa. Mod Pathol. 2000;13(6):644-53.

28 de Villiers EM, Weidauer H, Otto $\mathrm{H}$, zur Hausen $\mathrm{H}$. Papillomavirus DNA in human tongue carcinomas. Int J Cancer. 1985;36(5):575-78.

29 Syrjanen SM, Syrjanen KJ, Happonen RP. Human papillomavirus (HPV) DNA sequences in oral precancerous lesions and squamous cell carcinoma demonstrated by in situ hybridization. J Oral Pathol. 1988;17(6):273-78.

30 Zeuss MS, Miller CS, White DK. In situ hybridization analysis of human papillomavirus DNA in oral mucosal lesions. Oral Surg Oral Med Oral Pathol. 1991;71(6):714-20.

31 Shindoh M, Sawada Y, Kohgo T, Amemiya A, Fujinaga K. Detection of human papillomavirus DNA sequences in tongue squamous-cell carcinoma utilizing the polymerase 
chain reaction method. Int J Cancer. 1992;50(2):167-71.

32 Ostwald C, Muller P, Barten M, Rutsatz K, Sonnenburg M, Milde-Langosch K, et al. Human papillomavirus DNA in oral squamous cell carcinomas and normal mucosa. J Oral Pathol Med. 1994;23(5):220-25.

33 Balaram P, Nalinakumari KR, Abraham E, Balan A, Hareendran NK, Bernard HU, et al. Human papillomaviruses in 91 oral cancers from Indian betel quid chewers-high prevalence and multiplicity of infections. Int J Cancer. 1995;61(4):450-54.

34 Cruz IB, Snijders PJ, Steenbergen RD, Meijer CJ, Snow GB, Walboomers JM, et al. Age-dependence of human papillomavirus DNA presence in oral squamous cell carcinomas. Eur J Cancer B Oral Oncol. 1996;32B(1):55-62.

35 Elamin F, Steingrimsdottir H, Wanakulasuriya N, Johnson, N, Tavassoli M. Prevalence of human papillomavirus infection in premalignant and malignant lesions of the oral cavity in U.K. subjects: a novel method of detection. Oral Oncol. 1998;34(3):191-97.

36 Matzow T, Boysen M, Kalantari M, Johansson B, Hagmar B. Low detection rate of HPV in oral and laryngeal carcinomas. Acta Oncol. 1998;37(1):73-76.

37 Gillison ML, Koch WM, Capone RB, Spafford M, Westra WH, Wu L, et al. Evidence for a causal association between human papillomavirus and a subset of head and neck cancers. J Natl Cancer Inst. 2000;92(9):709-20.

38 Sisk EA, Bradford CR, Jacob A, Yian CH, Staton KM, Tang G, et al. Human papillomavirus infection in "young" versus "old" patients with squamous cell carcinoma of the head and neck. Head Neck. 2000;22(7):649-57.

39 Uobe K, Masuno K, Fang YR, Li LJ, Wen YM, Ueda Y, et al. Detection of HPV in Japanese and Chinese oral carcinomas by in situ PCR. Oral Oncol. 2001;37(2):146-52.

40 Nagpal JK, Patnaik S, Das BR. Prevalence of high-risk human papilloma virus types and its association with $\mathrm{p} 53$ codon 72 polymorphism in tobacco addicted oral squamous cell carcinoma (OSCC) patients of Eastern Indian. Int J Cancer. 2002;97(5):649-53.

41 Chang JY, Lin MC, Chiang CP. High-risk human papillomaviruses may have an important role in non-oral habits-associated oral squamous cell carcinomas in Taiwan. Am J Clin Pathol. 2003;120(6):909-16.
42 Báez A, Almodóvar JI, Cantor A, Celestin F, Cruz-Cruz L, Fonseca $S$, et al. High frequency of HPV 16-associated head and neck squamous cell carcinoma in the Puerto Rican population. Head Neck. 2004;26(9):778-84.

43 Zhang ZY, Sdek P, Cao J, Chen WT. Human papillomavirus type 16 and 18 DNA in oral squamous cell carcinoma and normal mucosa. Int J Oral Maxillofac Surg. 2004;33(1):71-74.

44 Ibieta BR, Lizano M, Frías-Mendivil M, Barrera JL, Carrillo A, Ruíz-Godoy LM, et al. Human papilloma virus in oral squamous cell carcinoma in Mexican population. Oral Surg Oral Med Oral Pathol Oral Radiol Endod. 2005;99(3):311-15.

45 Tachezy R, Klozar J, Saláková M, Smith E, Turek L, Betka J, et al. HPV and other risk factors of oral cavity/ oropharyngeal cancer in the Czeh Republic. Oral Dis. 2005;11(3):181-85.

46 Nemes JA, Deli L, Nemes Z, Márton IJ. Expression of $\mathrm{p} 16 \mathrm{INK} 4 \mathrm{~A}, \mathrm{p} 53$, and $\mathrm{Rb}$ proteins are independent from the presence of human papillomavirus genes in oral squamous cell carcinoma. Oral Surg Oral Med Oral Pathol Oral Radiol Endod. 2006;102(3):344-52.

47 Rivero ERC, Nunes FD. HPV in oral squamous cell carcinomas of a Brazilian population: amplification by PCR. Braz Oral Res. 2006;20(1):21-24.

48 Miller CS, White DK. Human papillomavirus expression in oral mucosa, premalignant conditions, and squamous cell carcinoma: a retrospective review of the literature. Oral Surg Oral Med Oral Pathol Oral Radiol Endod. 1996;82(1):57-68.

49 Campisi G, Giovannelli L, Ammatuna P. Human papillomavirus frequency in oral epithelial lesions. J Oral Pathol Med. 2005;34(1):62-64.

50 Sugerman PB, Shillitoe EJ. The high risk human papillomaviruses and oral cancer: evidence for and against a causal relationship. Oral Dis. 1997;3(3):130-47.

51 Stubenrauch F, Laimins LA. Human papillomavirus life cycle: active and latent phases. Cancer. 1999;9(6):379-86.

52 Chang F, Syrjanen S, Kellokoski J, Syrjanen K. Human papillomavirus (HPV) infections and their associations with oral disease. J Oral Pathol Med. 1991;20(7):305-17.

53 Terai M, Takagi M. Human papillomavirus in the oral cavity. Oral Med Pathol. 2001;6:1-12.

\section{Abstract}

Recent studies using new viral detection technologies point to human papillomavirus (HPV) as the etiological agent of uterine cervical cancer. Other anatomical sites besides the genital area can be infected by HPV, mainly the head and neck. The direct involvement of HPV in oral carcinoma has still not been fully proven, but its synergism with chemical and physical carcinogens in some squamous cell carcinomas appears to be the most likely explanation for the role of HPV in oral carcinogenesis.

Key words: Human papillomavirus, Carcinogenesis, Oral cancer 